\title{
Differential Roles of Endothelin-1 in Angiotensin II-Induced Atherosclerosis and Aortic Aneurysms in Apolipoprotein E-Null Mice
}

\author{
Renée S. Suen, ${ }^{* \dagger}$ Sarah N. Rampersad, ${ }^{\ddagger}$ \\ Duncan J. Stewart, ${ }^{* \ddagger}$ and David W. Courtman ${ }^{\ddagger}$ \\ From the Terrence Donnelly Research Laboratories," Division of \\ Cardiology, St. Michael's Hospital, Toronto; the Institute of \\ Medical Science, ${ }^{\dagger}$ University of Toronto, Toronto; and the Ottawa \\ Hospital Research Institute, Ottawa, Ontario, Canada
}

Because both endothelin-1 (ET-1) and angiotensin II (AngII) are independent mediators of arterial remodeling, we sought to determine the role of ET receptor inhibition in AngII-accelerated atherosclerosis and aortic aneurysm formation. We administered saline or AngII and/or bosentan, an endothelin receptor antagonist (ERA) for 7, 14, or 28 days to 6-week- and 6-monthold apolipoprotein E-knockout mice. AngII treatment increased aortic atherosclerosis, which was reduced by ERA. ET-1 immunostaining was localized to macrophage-rich regions in aneurysmal vessels. ERA did not prevent AngII-induced aneurysm formation but instead may have increased aneurysm incidence. In AngIItreated animals with aneurysms, ERA had a profound effect on the non-aneurysmal thoracic aorta via increasing wall thickness, collagen/elastin ratio, wall stiffness, and viscous responses. These observations were confirmed in acute in vitro collagen sheet production models in which ERA inhibited AngII's dose-dependent effect on collagen type $1 \alpha 1$ (COL1A1) gene transcription. However, chronic treatment reduced matrix metalloproteinase 2 mRNA expression but enhanced COL3A1, tissue inhibitor of metalloproteinase 1 (TIMP-1), and TIMP-2 mRNA expressions. These data confirm a role for the ET system in AngII-accelerated atherosclerosis but suggest that ERA therapy is not protective against the formation of AngII-induced aneurysms and can paradoxically stimulate a chronic arterial matrix remodeling response. (Am J Pathol 2011, 179:1549-1559; DOI: 10.1016/j.ajpath.2011.05.014)

Atherosclerosis and aneurysmal vascular diseases lead to substantial morbidity and mortality, and they share a number of clinical risk factors. ${ }^{1}$ Both diseases are associated with inflammation, and, although some believe that advanced atherosclerosis may be a prerequisite for abdominal aortic aneurysm (AAA), not all patients with $A A A$ have evidence of substantial atherosclerosis nor does atherosclerosis always lead to aneurysm formation. Indeed, several studies have suggested that aneurysms and atherosclerosis are influenced by distinctly different inflammatory processes with $\mathrm{T}$ helper (Th) 1 cytokines predominating in atherosclerosis and Th2 responses predominating in aneurysms. ${ }^{2-4}$ Nevertheless, both diseases share common pathologic mechanisms, including protease-mediated matrix degradation ${ }^{5,6}$ and the generation of reactive oxygen species, ${ }^{7}$ that suggest the utility of a common therapeutic approach toward each condition. However, it is also possible that potential therapeutic approaches may have divergent effects on both AAA and atherosclerosis.

Angiotensin II (Angll) has been associated with atherosclerosis and aneurysm rupture in humans ${ }^{8,9}$; in lowdensity lipoprotein receptor, or apolipoprotein E-deficient $\left(a_{0} E^{-/-}\right)$mice, Angll infusion accelerates atherosclerosis and induces aneurysm formation in the suprarenal aorta. ${ }^{9-21}$ The Angll/apoE ${ }^{-1-}$ mouse model is well characterized and represents the best model of combined atherosclerosis and aneurysm initiation; the striking features of this model are a marked infiltration of macrophages into the adventitia and media, the breakdown of elastin lamellae, and the development of marked dilation of the suprarenal aorta. ${ }^{13,22}$ Of interest, atherosclerosis and AAA in this model occur independent of increased blood pressure, a risk factor traditionally associated with

Supported by the Canadian Institutes of Health Research (CIHR) operating grant MOP-74752, the Pfizer/Canadian Hypertension Society/CIHR RxD Doctoral Research Award, and the Heart \& Stroke/Richard Lewar Center of Excellence.

Accepted for publication May 17, 2011

Bosentan was provided by Actelion Pharmaceuticals Ltd., Switzerland, and the LU409422 compound was provided by Abbott GmbH \& Co. KG, Wiesbaden-Delkenheim, Germany.

Address reprint requests to David W. Courtman, Ph.D., Ottawa Health Research Institute, 501 Smyth Rd., Ottawa, ON, Canada K1H 8L6. E-mail: dcourtman@ohri.ca. 
both diseases. ${ }^{10,16,21}$ Although hyperlipidemia itself has been shown to induce the development of AAA in aged apoE ${ }^{-1-}$ mice, ${ }^{23}$ the incidence remains low but is markedly increased by Angll infusion. Pathologic differences may exist between young and old animals, and an appropriate comparison of the two under identical experimental conditions may help elucidate the importance of age and/or the presence of pre-existing lesions on AAA development.

Endothelin (ET)-1 is known to play an important role in atherogenesis, ${ }^{24-26}$ yet its contribution to the formation of aneurysms is largely unknown. ET-1 is an important downstream mediator of many of the biological effects of Angll, having a pivotal role in vascular remodeling. ${ }^{27}$ Moreau et $\mathrm{al}^{28}$ reported that increased arterial smooth muscle cell (SMC) hypertrophy in Angll-infused rats was completely inhibited with the administration of a selective ET(A)-receptor antagonist, LU135252. In this study, we have examined young and old apoE-null mice, confirming a modest contribution of ET-1 to atherogenesis in the Angll-infused model but also providing evidence of a previously unrecognized protective role for the ET-1 pathway in limiting the extent of fibrosis and remodeling of the aneurysmal matrix.

\section{Materials and Methods}

\section{Animals and Design}

Young (4 weeks) and old (6 months) apoE ${ }^{-1-}$ mice (The Jackson Laboratory, Bar Harbor, ME) were examined for atherosclerotic progression and aneurysm formation after infusion with Angll with or without bosentan (Tracleer; Actelion Pharmaceuticals Ltd., Allschwil, Switzerland), a dual ET-1 receptor antagonist (ERA). Four-week-old mice $(n=180)$ were fed a Western-type diet (TD 88137; Harlan Teklad, Madison, WI) beginning 2 weeks before experimentation (mean cholesterol, $27.49 \pm 1.63 \mathrm{mmol} / \mathrm{L}$; mean triglyceride, $1.42 \pm 0.17 \mathrm{mmol} / \mathrm{L}$ at sacrifice) to encourage lesion progression, and 6-month-old mice $(n=194)$ received normal chow. Invasive procedures were performed under anesthesia (xylazine $20 \mathrm{mg} / \mathrm{kg}$ and ketamine $100 \mathrm{mg} / \mathrm{kg}$ ). All animal studies were conducted under protocols approved by the local animal care committee in accordance with guidelines from the Canadian Council of Animal Care.

\section{In Vivo Model}

Mice were randomly assigned to receive a 4-week infusion of either Angll (1000 $\mathrm{ng} \cdot \mathrm{kg}^{-1} \cdot$ minute ${ }^{-1}$; A9525; Sigma-Aldrich, St. Louis, $\mathrm{MO}$ ) or $0.9 \% \mathrm{NaCl}$ by a subcutaneous osmotic minipump (Model 2004; Durect Corporation, Cupertino, CA). Mice assigned ERA received 10 $\mathrm{mg} \cdot \mathrm{kg}^{-1} \cdot$ day $^{-1}$ bosentan in their drinking water (a dose that significantly inhibited acute ET-1-induced rise in systemic blood pressure). After 4 weeks of treatment blood pressure was measured from the right common carotid artery with a fluid-filled catheter. Blood was extracted through cardiac puncture into EDTA vials, spun down $(250 \times g)$ and the plasma stored at $-80^{\circ} \mathrm{C}$. The arterial system was perfusion fixed with $4 \%$ paraformaldehyde at $70 \mathrm{mmHg}$ pressure, and the aorta (arch to the iliac bifurcation) was removed, stripped of its adventitia, and photographed. Aneurysms were determined to be present if the widest region of the suprarenal aorta was 1.5 times greater than the upstream descending aorta. En face oil red O staining (O0625; Sigma-Aldrich) ${ }^{25}$ was used to evaluate the percentage of luminal surface area occupied by lipid (atherosclerosis) in non-aneurysmal vessels with the use of ImageJ64 analysis software version 1.44 (National Institutes of Health, Bethesda, MD).

Serum total cholesterol and triglyceride concentrations were measured with an enzymatic cholesterol assay in a colorimetric procedure on a Technicon RA1000 analyzer (Bayer, Tarrytown, NY; $n=6$ ). ET-1 levels from precipitated plasma samples after 2 and 4 weeks of treatment were analyzed through enzyme-linked immunosorbent assay (ELISA) with the use of commercially available kits [Endothelin (1-21) ELISA Immunoassay; ALPCO Diagnostics, Salem, NH] according to manufacturer's recommendations.

\section{Tissue Mechanics Analysis}

Aortas from a subset of the 6-month-old animals underwent uniaxial mechanical testing ( $n=10$ to 20). A 2-mm ring of the thoracic aorta was excised between the aortic arch and intercostal arteries and mounted between two orthodontic wire loops (0.4-mm diameter) to avoid gripping artifacts. The loops were mounted on a Mach-1 Micromechanical Test System (Biosyntech, Montreal, QC, Canada) to allow for the precise actuator-based circumferential extension of the tissue while load was recorded with a 1000-g load cell. During testing tissue was submersed in oxygenated Krebs solution $(\mathrm{pH} 7.4$, and $37^{\circ} \mathrm{C}$ ) containing $0.8 \mathrm{~g} / \mathrm{L}$ papaverine (P3510; SigmaAldrich). A digital image of the tissue at $0.1-g$ resting tension was captured to determine segment (gauge) length and width. Stress was calculated from the wall thickness values measured from digital images of sections adjacent to the excised ring. Tissues were preconditioned at 20 cycles to 7 -g load (approximately $15 \%$ of maximum load) with a strain rate of $10 \mathrm{~mm} /$ minute. For stress relaxation testing, tissues were loaded to $7 \mathrm{~g}$, and the load decay was observed for 100 seconds. Finally, tissues were preconditioned as above before loading at $10 \mathrm{~mm} /$ minute to fracture.

\section{Collagen and Elastin Quantification}

All chemicals are from Sigma-Aldrich unless specified. Tissues were dried and digested in cyanogen bromide (50 $\mathrm{mg} / \mathrm{mL}$ in $70 \%$ in formic acid), and the supernatant fluid, along with the washed pellet, was collected and separately hydrolyzed overnight at $110^{\circ} \mathrm{C}$ in $6 \mathrm{~N} \mathrm{HCl}$. Total collagen was determined with the hydroxyproline assay modified from Huszar et al. ${ }^{29}$ The supernatant fluid was reconstituted in collagen assay buffer $(0.26 \mathrm{~mol} / \mathrm{L}$ citric acid, $0.21 \mathrm{~mol} / \mathrm{L}$ glacial acetic acid, $0.88 \mathrm{~mol} / \mathrm{L}$ sodium acetate $3 \mathrm{H}_{2} \mathrm{O}, 0.85 \mathrm{~mol} / \mathrm{L}$ sodium hydroxide; $\mathrm{pH}$ 6.0) and free hydroxyproline in the sample was analyzed by react- 
ing with Chloramine $T(0.5 \mathrm{~mol} / \mathrm{L}$ in $\mathrm{n}$-propanol; Fisher Scientific, Ottawa, ON, Canada) for 20 minutes, then with Ehrlich solution and perchloric acid $\left(15\right.$ minutes at $\left.65^{\circ} \mathrm{C}\right)$, and followed with absorbance reading at $550 \mathrm{~nm}$ against a hydroxyproline standard $(\mathrm{pH} 6)$. Total collagen was calculated by assuming a $12.7 \%$ hydroxyproline content. Elastin content was determined as total protein (Ninhydrin assay) in the cyanogen bromide-insoluble pellet with absorbance read at $570 \mathrm{~nm}$ against a hydrolyzed elastin standard. Elastin purity was confirmed in four samples through amino acid analysis by quadrupole time-of-flight mass spectrometry (Advanced Protein Technology Centre, Hospital for Sick Children, Toronto, ON, Canada).

\section{Histologic and IHC Staining}

Cross-sections spanning the length of the aorta were stained with H\&E, Verhoeff's van Gieson, and picosirius red. Routine immunohistochemistry $(\mathrm{IHC})$ was performed with the following primary antibodies: Angll (rabbit polyclonal, 1:1000; IHC7002; Peninsula Laboratories, Inc., San Carlos, CA), mouse ET-1 (rabbit polyclonal, 1:600; IHC6901; Peninsula Laboratories, Inc.), and mouse macrophage (rat polyclonal Mac-3, 1:10; 550292; BD Pharmingen, Franklin Lakes, NJ). A substitution with pre-immune serum in place of the primary and/or secondary antibodies was used as negative controls. Quantification of Mac-3 staining in intimal areas was performed with digital planimetry.

Apoptosis was detected with the DeadEnd Fluorometric TUNEL System (G3250; Promega, Madison, WI), and data were confirmed by immunostaining with fluoresceinconjugated cleaved caspase-3 (Asp175) antibody (1: 100; 9667; Cell Signaling Technology, Danvers, MA). Slides were also stained with cyanine 3-conjugated monoclonal anti- $\alpha$-smooth muscle actin (1:200; C6198; Sigma-Aldrich) and ToPro3 nuclear counterstain (1:5000; T3605; Invitrogen, Carlsbad, CA). Fluorescence intensity was quantified by a blinded observer, using a fixed gain and power setting on a Nikon (Melville, NY) fluorescent microscope equipped with an epi-illumination singleband emitter filter cassette for the separate illumination of green $(543 \mathrm{~nm})$, red $(633 \mathrm{~nm})$, and blue (488 nm) fluorescence.

\section{SMC Culture Model of Collagen Sheet}

\section{Production}

Rat A10 SMC (CRL-1476; American Type Culture Collection, Manassas, VA) from passages 14 to 17 were cultured at an initial density of 10,000 cells/cm ${ }^{2}$ in Dulbecco's modified Eagle's medium supplemented with $10 \%$ fetal bovine serum and penicillin/streptomycin (100 U/100 $\mu \mathrm{g} / \mathrm{mL}$ ). At confluence, cultures were fed daily with freshly prepared 50 $\mu \mathrm{g} / \mathrm{mL}$ L-ascorbic acid (A7631; Sigma-Aldrich) to encourage collagen production for a total of 28 days. At 15 days of ascorbate supplementation flasks were randomized to receive supplementation with Angll $\left(10^{-7} \mathrm{~mol} / \mathrm{L}\right.$; Sigma-Aldrich), ERA ( $\left.10^{-5} \mathrm{~mol} / \mathrm{L}\right)$, both compounds, or vehicle ( $n=$ 9 to 10 separate experiments).

\section{Quantitative Real-Time RT-PCR}

Total RNA was extracted from collagen sheets with the use of the RNeasy MiniKit (74104; Qiagen, Valencia, CA) with the on-column DNase digestion step (RNase-Free DNase Set; 79254; Qiagen). Total RNA (1 $\mu \mathrm{g})$ was reverse transcribed to first-strand cDNA with the use of the Omniscript RT Kit (205111; Qiagen). Primer sequences used for collagen type $3 \alpha 1$ (COL3A1), ${ }^{30}$ membrane type-1 matrix metalloproteinase (MMP), tissue inhibitor of metalloproteinase (TIMP)-1, and TIMP-2 ${ }^{31}$ are the same as previously described. Primer sets used for collagen type $1 \alpha \alpha$ (COL1A1) was 5'-AAGGTTCTCCTGGTGAAGCTG-3' and 5'-ATCACACCAGCCTGTCCACGG3', MMP-2 was 5'-ACACTGGGACCTGTCACTCC-3' and 5'-ACACGGCATCAATCTITCC-3', and interferon (IFN)- $\gamma$ was 5'-GCCCTCTCTGGCTGTTACTG-3' and 5'-CCAAGAGGAGGCTCTTTCCT-3'. CDNA amplification for each gene of interest was monitored with $2 \times$ SYBR Green PCR Master Mix (4309155; Applied Biosystems, Carlsbad, CA) with the use of the ABI PRISM Sequence Detection System (model 7900HT SDS, Applied Biosystems). All results were normalized to glyceraldehyde-3-phosphate dehydrogenase (GAPDH) expression (TaqMan Rodent GAPDH Control Reagents kit; 4308313; Applied Biosystems). mRNA levels were calculated with the $\Delta \Delta \mathrm{Ct}$ formula: target gene expression/GAPDH expression = $2^{(\Delta \Delta \mathrm{C})}$ and are reported in arbitrary units.

\section{Adhesion Assay}

Rat A10 cells were treated with Angll, ERA, both compounds, or vehicle ( $n=3$ to 4 per group) for 24 hours before being serum starved overnight. Cells were then harvested with trypLE (12563029; Invitrogen), incubated in serum-free Dulbecco's modified Eagle's medium for 1 hour, and plated at 26,000 cells $/ \mathrm{cm}^{2}$ on plates precoated with type I collagen (PICL24P05; Millipore, Bellerica, MA). Cells were incubated for 1.5 hours at $37^{\circ} \mathrm{C}$, and nonadherent cells were removed by washing with PBS. Six to eight images per treatment group were taken at $\times 10$ magnification under an inverted light microscope, and the number of adherent cells per field were counted.

\section{Flow Cytometry}

Rat A10 SMCs pretreated for 24 hours with Angll, ERA, both compounds, or vehicle ( $n=3$ to 4 ) were harvested with $2 \mathrm{mmol} / \mathrm{L}$ EDTA (E9884; Sigma-Aldrich) and resuspended at 1000,000 cells $/ \mathrm{mL}$ in staining buffer $(1 \%$ bovine serum albumin, $0.1 \%$ sodium azide in PBS) containing anti- $\beta_{1}$-integrin antibody (mouse monoclonal, 1:500; MAB1965; Millipore) or mouse IgG1 isotype control (human, 1:500; 11-632-C100; Axxora, San Diego, CA) for 1 hour. Cells were centrifuged (400 $\times$ g, 5 minutes), washed, and incubated with Alexa Fluor 488 (goat polyclonal, 1:1000; A11001; Invitrogen) for 1 hour in the dark. Cells were washed, resuspended in staining buffer, and analyzed with a Cell Lab Quanta SC system (Beckman Coulter, Mississauga, ON, Canada). 


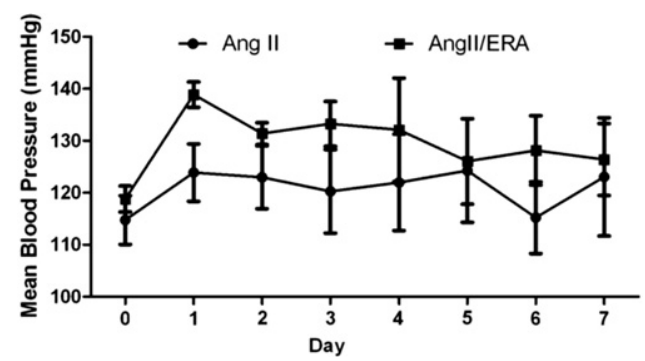

Figure 1. Daily mean blood pressure measurements, starting 7 days after initial telemetry implantation. Day 0 represents the beginning of treatment with either AngII or AngII/ERA for 7 days. At day 7, no significant difference was observed between the treatment groups; $n=3$ to 4 .

\section{Statistical Analysis}

$\chi^{2}$ testing was used to determine the significance of aneurysm incidence. Quantitative results are expressed as mean \pm SEM unless otherwise stated, and differences were determined by nonpaired $t$-test, or one-way analysis of variance with post hoc tests performed with Bonferroni's or Dunnet's multiple comparison tests when appropriate. For tissue mechanics, the nonparametric KruskalWallis test was used. Analyses were performed with GraphPad Prism version 5 (GraphPad Software, Inc., San Diego, CA). $P$ values $<0.05$ were considered significant.

\section{Results}

\section{Characterization of Animal Model}

Mean arterial blood pressure was not significantly different in any of the treatment groups of the same age when measured under anesthetic conditions. In vivo telemetric blood pressure measurements were also performed in a subset of 8-week-old mice with the use of implantable telemetry (DSI PhysioTel PA-C10; Data Sciences International, St. Paul, MN) by carotid catheter placement. Measurements were taken for 1 hour, twice daily for 7 days to establish a baseline control, then treated with Angll $(n=$ 3 ) or combined Angll and ERA $(n=4)$ for 7 days. These animals showed a modest increase in blood pressure measured after 7 days of treatment compared with baseline $(101.2 \pm 2.75 \mathrm{mmHg}$ versus $124.9 \pm 5.71 \mathrm{mmHg}$; $P<0.05 ; n=7$ for control versus treatment); however, no differences in mean arterial blood pressure between Angll and Angll/ERA treatment groups were observed (Figure 1). Plasma cholesterol and triglyceride concentrations were not significantly different in any of the treatment groups of the same age. Plasma concentrations of ET-1 from Angll-treated young mice were not elevated after 2 weeks (10.98 $\pm 1.92 \mathrm{fmol} / \mathrm{mL})$ but trended higher by week 4; however, this was not statistically significant over controls (young: $15.36 \pm 3.38$ $\mathrm{fmol} / \mathrm{mL}$ versus $7.94 \pm 1.98 \mathrm{fmol} / \mathrm{mL}, P=0.10$; old: $12.92 \pm$ $2.97 \mathrm{fmol} / \mathrm{mL}$ versus $7.68 \pm 2.20 \mathrm{fmol} / \mathrm{mL}, P=0.25$; $n=10$ to 14 for Angll versus control); old mice treated with ERA did show a significant increase in plasma ET-1 (young: $13.27 \pm 2.20 \mathrm{fmol} / \mathrm{mL}, P=0.09, n=12$; old: $19.87 \pm 1.85 \mathrm{fmol} / \mathrm{mL}, P<0.01, n=5$ for ERA versus control). ET-1 immunostaining was seen mainly in the intima and media of aortas from Angll-treated animals, regions that often stained positive for the macrophage marker Mac-3 (Figure 2A). ERA was able to diminish ET-1 staining in aortic cross-sections from old Angll-treated animals (Figure 2A).

\section{Angll-Induced Atherosclerosis Is Partially Mediated by ET-1}

Angll-treated 6-week-old mice showed an eightfold $(P<$ 0.001 ) increase in en face lesion area (Figure 2B), whereas 6-month-old mice had a threefold increase $(P<$ 0.01) compared with age-matched controls (Figure $2 \mathrm{C}$ ). Administration of ERA reduced Angll-induced lesion area in the young mice $(P<0.01)$ but not in the old animals,
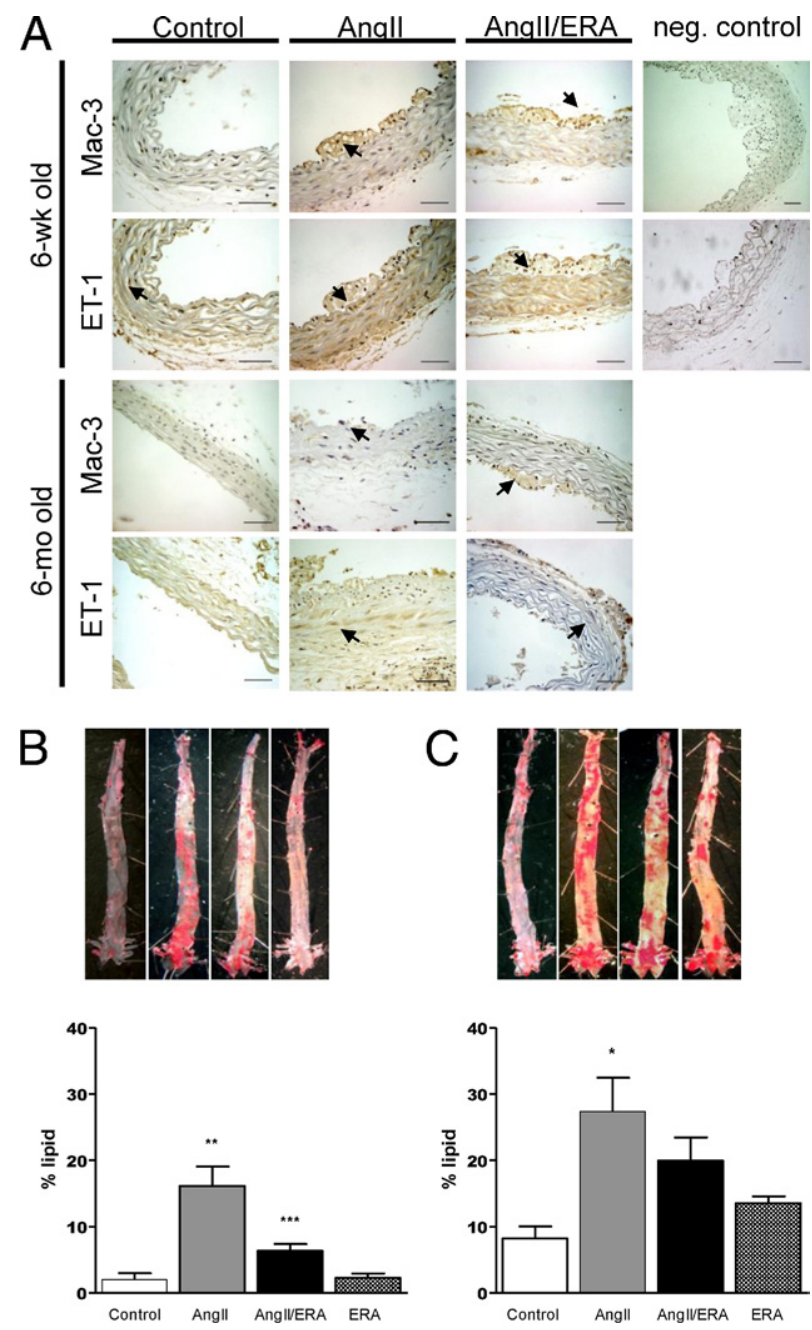

Figure 2. ET antagonism in AngII-accelerated atherosclerosis. A: Representative photomicrographs of ET-1 and Mac-3 immunostaining in control, AngII, or AngII/ERA mouse thoracic aortas (brown indicates positive immunostaining; arrows, blue, hematoxylin for cell nuclei). Scale bar $=50 \mu \mathrm{m}$. En face oil red O-stained aortas from mice 6 weeks old (B) and 6 months old (C), and percentage of en face intimal surface area positive for oil red $\mathrm{O}$ staining measured in both age groups. Quantification was performed by two independent observers. Data are presented as means \pm SEM; $n=6$ to 10 . ${ }^{*} P<0.01$ versus age-matched control; ${ }^{* *} P<0.001$ versus all groups; and **** $P<0.01$ AngII/ERA versus AngII 
possibly because of the presence of pre-existing lesions in the aortas of older $\mathrm{apoE}^{-/-}$mice. ${ }^{32,33}$

\section{Angll Treatment Induces Aneurysm Development and Increases ET-1 Production and Macrophage Infiltration in the Suprarenal Aorta}

Saline-treated $\mathrm{apoE}^{-/-}$mice did not develop AAA (Figure $3 A$ ). In all groups of Angll-infused mice, a subset exhibited histologic evidence of aneurysm formation in the suprarenal aorta, including thickened media and adventitial layers, and disruptions to the elastic lamina (Figure 3). To our surprise, ERA failed to protect against Angll-induced AAA formation. Both Angll and Angll/ERA groups produced a significant increased incidence of aneurysms compared with controls (Figure 3, A, C, and D). Although the incidence of AAA in the Angll/ERA groups were 1.5- and 1.3-fold higher in young and old mice than in mice treated only with Angll, this did not reach statistical significance in a $\chi^{2}$ analysis (young: 20.6\% Angll versus 32.6\% Angll/ERA; old: 37.7\% Angll versus $50.7 \%$ Angll/ERA; Figure $3, \mathrm{C}$ and $\mathrm{D} ; P<0.001$ ). A power analysis (power of $80 \%, \alpha=0.05$ ) showed that the test of incidence at this level of difference is relatively insensitive and would require unfeasible group sizes $(>300)$. These observations were confirmed in a separate study that used LU409422 $\left(10 \mathrm{mg} \cdot \mathrm{kg}^{-1} \cdot\right.$ day $^{-1}$; Abbott GmbH \& Co. KG, Wiesbaden-Delkenheim, Germany), a mixed ERA, in which co-administration of Angll and LU409422 resulted in $36.4 \%$ of young $(n=33)$ and $44.7 \%$ of old $(n=38) \mathrm{apoE}^{-1-}$ mice developing AAA.

Although old mice had a trend for higher incidence of AAA, no distinct histopathologic differences were observed in the aneurysms from either age group. In aneurysmal regions, macrophage infiltration was evident throughout the vessel wall and was extensive within the intima (Figure 3, B and $\mathrm{E}$ ). Regions of macrophage infiltration stained positive for Angll and ET-1. In vessels with aneurysmal dilatation, ET-1 immunostaining also extended to the media and adventitia layers of the thoracic aorta (Figure 3F). Changes in the cellular composition in the aorta of 6-month-old animals were examined with immunofluorescent staining after 1 and 2 weeks of treatment, before the aneurysms had become established. Angll increased SMCs in the media from both thoracic and suprarenal segments (Figure 4A); this hyperplastic effect was abrogated by ERA in the thoracic aorta. Apoptosis (TUNEL and cleaved caspase-3 staining; data not shown) was extremely low in the media of all vessels, and treatment with Angll/ERA had no measurable effect (Figure 4, B and C).

\section{Collagen Content Is Modulated by the ET Pathway}

Collagen and elastin content of the thoracic tissues was measured. Fibrillar collagen was increased in the thoracic aorta in response to Angll/ERA treatment (Figure 5A; $P<$ $0.05)$, which was largely because of the profound increase seen in animals exhibiting suprarenal AAA (3.5-fold; Figure
A
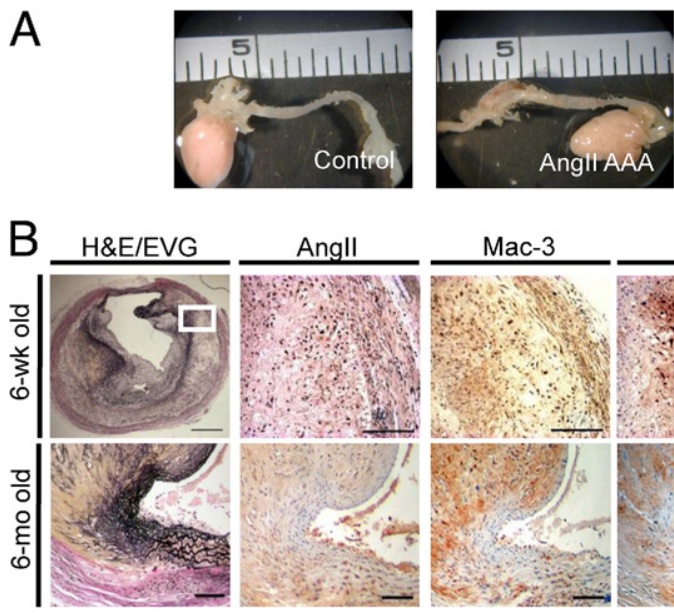

Angll

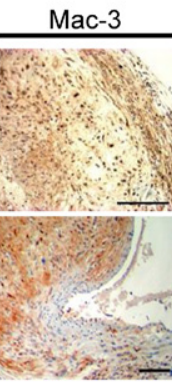

ET-1
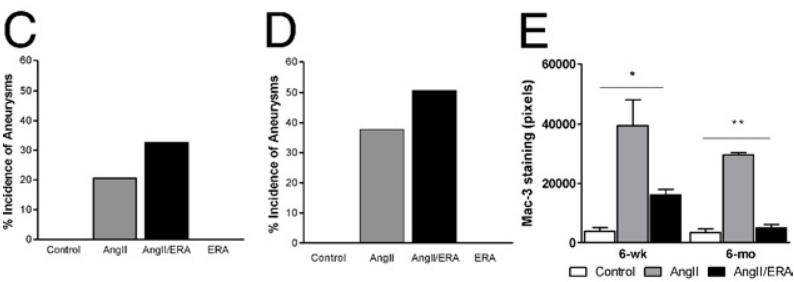

$\mathrm{F}$

Angll

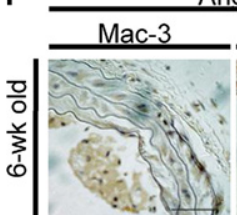
ET-1 Angll/ERA

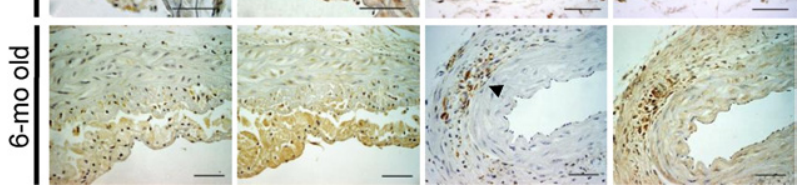

Figure 3. ET-antagonism in AngII-induced aneurysm formation. A: Representative photomicrographs of the control aneurysm-free and AngII-treated aneurysmal aortas extracted after 28 days, free of adventitia. B: Representative serial cross sections from a region in a suprarenal aneurysm from a 6-week- and 6-month-old AngII-treated animal immunostained for AngII, Mac-3, or ET-1. General histology was performed with Verhoeff's van Gieson staining for elastic fibers (black), hematoxylin for cell nuclei (blue), and counterstained with eosin (pink). IHC staining is shown at higher magnification taken from a section of the aneurysmal wall (region shown in the white box inset from the 6-week-old H\&E/Verhoeff's van Gieson-stained section). Scale bars: $500 \mu \mathrm{m}$ for 6-week-old mice with H\&E/Verhoeff's van Gieson staining; $50 \mu \mathrm{m}$ for all other sections. Prevalence of aneurysms found in 6-week-old (C) and 6-month-old (D) mice. No aneurysms were observed in mice not receiving AngII (saline-treated or ERA). E: Planimetric quantification showing ERA's ability to inhibit AngII-induced macrophage infiltration (Mac-3 staining) in the intima of thoracic aortas from 6-week- and 6-monthold mice. Data are presented as means \pm SEMs; $n=3$ to $7 .{ }^{*} P<0.05,{ }^{* * *} P<$ 0.0001 . F: Representative photomicrographs of thoracic aortas from aneurysmal vessels from a 6-week- and 6-month-old mouse infused with AngII or AngII/ERA. Immunostaining for Mac-3 and ET-1 were performed in serial cross sections (brown indicates positive immunostaining; blue, counterstaining with hematoxylin for cell nuclei). Arrowhead shows a concentrated pocket of macrophages in the adventitia. Scale bar $=50 \mu \mathrm{m}$.

5B). Elastin content remained unchanged in these vessels, resulting in marked elevation in the collagen/elastin ratio. Picosirius red-stained sections observed with circular polarized microscopy showed higher fibrillar collagen birefringence in the medial layer of thoracic aortas from the Angll/ ERA-treated mice with suprarenal aneurysms, compared with the other groups (Figure 5C). 
A

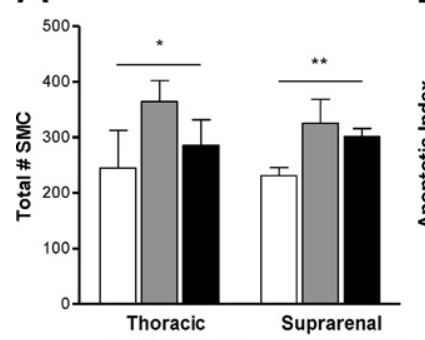

$\square$ Control $\square$ Angll $\square$ Angll/ERA

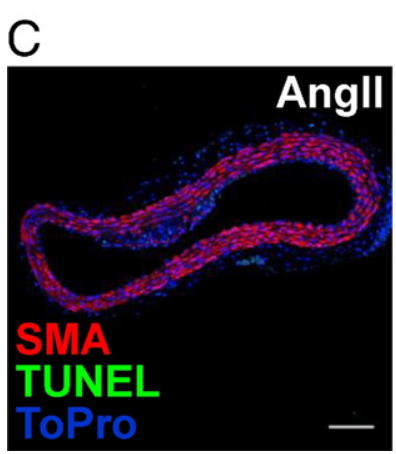

B

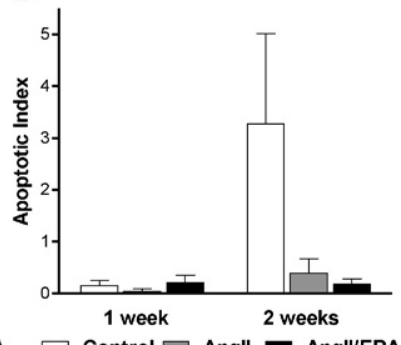

$\square$ Control $\square$ Angll $\square$ Angll/ERA

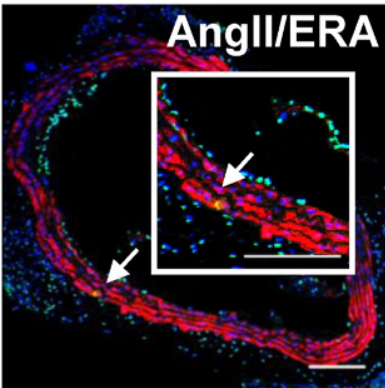

Figure 4. Cellular changes found in treated thoracic aortas. Quantification cells positive for SMC- $\alpha$ actin (A) and TUNEL (B) in animals treated for 1 and 2 weeks. The apoptotic index was determined by taking the number of apoptotic cells divided by the total population of those cells, multiplied by 100 . AngII induced a hyperplastic response in both thoracic and suprarenal aortic SMCs. Data are presented as means \pm SEMs; $n=11 .{ }^{*} P=0.001,{ }^{*}{ }^{*} P=0.005$. C: Representative confocal images show minor SMC apoptosis (yellow, arrow) in the AngItreated aortas. Higher magnification of vessel area is indicated by the photo inset. Colors indicate positive staining for apoptosis (green), SMC- $\alpha$ actin (red), and cell nuclei (blue). Scale bar $=50 \mu \mathrm{m}$.

\section{Biomechanical Properties of Aortas}

Functional changes in aortic structure were examined in thoracic aortic segments from 6-month-old mice. Angll/ ERA-treated mice exhibited increased wall thickness $(0.25 \pm 0.02 \mathrm{~mm}$ versus $0.15 \pm 0.03 \mathrm{~mm}$ for ERA control; $P<0.05)$, cross-sectional area $\left(0.73 \pm 0.10 \mathrm{~mm}^{2}\right.$ versus $0.37 \pm 0.03 \mathrm{~mm}^{2}$ for control; $P<0.05$ ), and vessel radius
$(0.50 \pm 02 \mathrm{~mm}$ versus $0.43 \pm 0.01 \mathrm{~mm}$ for control; $P<$ 0.01 ) of the thoracic aorta. A subset analysis showed that these changes were greatest in thoracic aortas from Angll/ERA-treated animals with suprarenal aneurysms (wall thickness, $0.31 \pm 0.04 \mathrm{~mm}$; cross-sectional area, $1.01 \pm$ $0.18 \mathrm{~mm}^{2}$; radius, $0.54 \pm 0.03 \mathrm{~mm}$ ).

Marked differences in stress-strain responses were observed between the groups (Figure 5D). The most pronounced biomechanical changes occurred in the thoracic aorta of Angll/ERA animals that developed suprarenal aneurysms. These changes were consistent with decreased elasticity and increased stiffness: elastic moduli (calculated at physiological stress levels) was substantially increased and stress-relaxation (percentage of stress remaining at 100 seconds) was reduced. Failure mechanics showed increased ultimate tensile stress and reduced yield strain in Angll/ ERA animals with aneurysms (Table 1). These mechanical results are consistent with an increased fibrillar collagen content.

\section{SMC Collagen Sheet Assays}

Confluent A10 cells were fed ascorbate for 2 weeks to encourage the deposition of a baseline collagen sheet, as described previously. ${ }^{34,35}$ Model validation was established through acute Angll dose-response studies that confirmed the up-regulation of COL1A1 mRNA with $\geq 10^{-7} \mathrm{~mol} / \mathrm{L}$ Angll (expression at 24 hours was greater than 6 hours by 15 -fold at $10^{-6} \mathrm{~mol} / \mathrm{L}$ and 43 -fold at $10^{-5}$ $\mathrm{mol} / \mathrm{L})$

\section{Long-Term Angll Treatment Suppresses Collagen Expression}

Because matrix turnover (collagen synthesis and degradation) will influence the total collagen accumulation in the long-term treatment model, we compared the total collagen harvested with qualitative real-time RT-PCR for genes known to regulate collagen production. No signif-

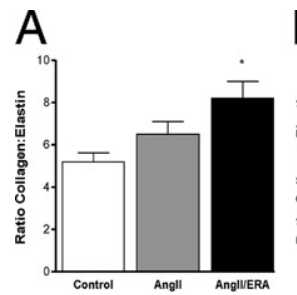

B

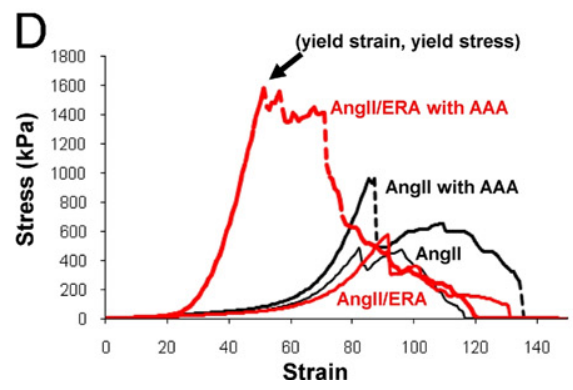

C
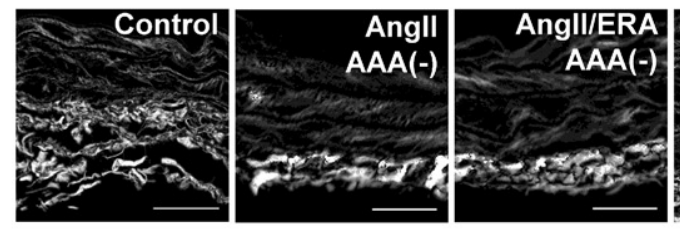

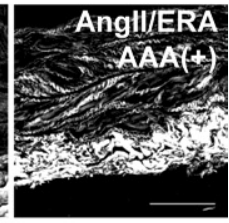

Figure 5. Matrix changes in treated thoracic aortas. Collagen/elastin was measured from all groups (A) and in aortas treated with AngII with (black) or without (open) aneurysms (B). Data are presented as means \pm SEMs; $n=8$ to $21 .{ }^{*} P<0.05,{ }^{* *} P<0.001$ versus control. C: Representative polescope images showing collagen birefringence of sections stained with picosirius red, showing increased fibrillar collagen in AAA from AngII/ERA tissues. Scale bar $=50 \mu \mathrm{m}$. D: Representative stress versus strain plots for vessels from mice treated with AngII (black) or AngII/ERA (red), with (dash) or without (solid) aneurysms in the suprarenal aorta. 
Table 1. Mechanical Testing as Quantified from the Thoracic Rings of 6-Month-Old, Treated $a p o E^{-/-}$Aortas

\begin{tabular}{|c|c|c|c|c|c|c|c|c|}
\hline & \multirow[b]{2}{*}{ Control } & \multicolumn{3}{|c|}{ Angll } & \multicolumn{3}{|c|}{ Angll/ERA } & \multirow[b]{2}{*}{ ERA } \\
\hline & & All aortas & $\begin{array}{l}\text { Without } \\
\text { AAA }\end{array}$ & With AAA & All aortas & $\begin{array}{l}\text { Without } \\
\text { AAA }\end{array}$ & With AAA & \\
\hline Number & 10 & 19 & 11 & 8 & 20 & 11 & 9 & 10 \\
\hline $\begin{array}{l}\text { Wall thickness, } \\
\text { mean } \pm \\
\text { SEM, mm }\end{array}$ & $0.17 \pm 0.02$ & $0.23 \pm 0.02$ & $0.20 \pm 0.02$ & $0.26 \pm 0.05$ & $0.25 \pm 0.02^{*}$ & $0.20 \pm 0.01$ & $0.31 \pm 0.04^{\dagger}$ & $0.15 \pm 0.03$ \\
\hline Number & 8 & 17 & 11 & 6 & 18 & 11 & 7 & 8 \\
\hline $\begin{array}{l}\text { Stress at } 100 \\
\text { seconds, } \\
\text { mean } \pm \\
\text { SEM, } \%\end{array}$ & $86 \pm 1$ & $79 \pm 3^{\ddagger}$ & $82 \pm 0.5^{\neq \neq}$ & $75 \pm 7$ & $71 \pm 5^{\ddagger}$ & $82 \pm 1$ & $54 \pm 9^{\dagger \dagger}$ & $83 \pm 1$ \\
\hline $\begin{array}{l}\text { Physiological } \\
\text { modulus, } \\
\text { mean } \pm \\
\text { SEM }\end{array}$ & $97 \pm 6$ & $106 \pm 4$ & $100 \pm 4$ & $115 \pm 8$ & $115 \pm 12$ & $92 \pm 3$ & $150 \pm 22^{\dagger}$ & $97 \pm 3$ \\
\hline $\begin{array}{l}\text { Yield stress, } \\
\text { mean } \pm \\
\text { SEM, kPa }\end{array}$ & $598 \pm 69$ & $721 \pm 102$ & $575 \pm 39$ & $922 \pm 224$ & $757 \pm 113$ & $527 \pm 38$ & $1072 \pm 226^{\dagger \dagger}$ & $591 \pm 53$ \\
\hline $\begin{array}{l}\text { Yield strain, } \\
\text { mean } \pm \\
\text { SEM, \% }\end{array}$ & $78 \pm 4$ & $77 \pm 3$ & $79 \pm 3$ & $74 \pm 5$ & $71 \pm 5$ & $84 \pm 2$ & $55 \pm 9^{\dagger \dagger}$ & $74 \pm 2$ \\
\hline
\end{tabular}

${ }^{\star} P<0.05$ versus ERA.

${ }^{\dagger} P<0.01,{ }^{\dagger} P<0.05$ verus non-aneurysmal aortas.

${ }^{\ddagger} P<0.05,{ }^{\ddagger \ddagger} P<0.01$ versus control.

icant increase in the percentage of total collagen (normalized to total protein) was found in this SMC sheet model after 2 weeks of Angll treatment (Figure 6A). Unlike the concentration-dependent up-regulation of COL1A1 mRNA during acute stimulation with $\geq 10^{-7}$ $\mathrm{mol} / \mathrm{L}$ Angll, transcript levels were suppressed after 2 weeks of continuous Angll treatment $(P<0.05)$; a similar trend was found with COL3A1 mRNA expression (Figure 6B; $P=0.06$ ). This may be due to a context-dependent transcriptional response that involves the negative feedback regulation of type I collagen. ${ }^{36,37}$ Quantitative realtime RT-PCR examination for regulators of tissue proteolysis showed a trend toward increased transcription of MMP-2 $(P=0.05)$ and decreased TIMP-1 and TIMP-2 mRNA expression (Figure 6C; $P=0.1$ and $P<0.05$, respectively) in the Angll groups.

\section{ERA Encourages a Fibrotic Response in the Angll-Stimulated Matrix}

Continuous treatment with a combination of Angll and ERA for 2 weeks nearly doubled collagen content (Figure $6 A$ ). Treatment with ERA was able to overcome the repressive effects of Angll on the matrix by maintaining baseline levels of COL1A1 mRNA (Figure 6D; $P<0.01$ ), enhancing COL3A1 mRNA expression $(P<0.005)$ and suppressing MMP-2 transcription (Figure $6 \mathrm{E} ; P<0.05$ ). Blockade of ET receptors during Angll stimulation was found to markedly induce TIMP-1 and TIMP-2 mRNA expression (Figure 6E; $P<0.005$ ). No changes in membrane type-1 MMP transcripts were found (data not shown).

\section{Angll/ERA Reduces Cellular Adhesion to Type I Collagen, Mediated in Part by Decreased $\beta_{1}$-Integrin Expression}

Because cellular adhesion can regulate extracellular matrix synthesis, we looked at changes in adhesion to type I collagen after treatment with Angll, ERA, or Angll/ERA combined. ERA treatment alone compared with control cells showed a trend for decreased adhesion to type I collagen $(64.62 \% \pm 8.02 \%$ normalized to control; $n=4)$, and Angll/ERA cells displayed a significant decrease in adhesion compared with Angll treatment alone (108.1\% \pm $17.29 \%$ versus $50.88 \% \pm 5.22 \%$ normalized to control; $n=3 ; P<0.05$; Figure 6F). Furthermore, specific analysis of major type I collagen receptor, $\beta_{1}$-integrin, by flow cytometry showed a marked decrease in $\beta_{1}$-integrin expression in cells treated with ERA alone (59\% reduction) and cells given a combination of Angll and ERA (67\% reduction) compared with controls.

\section{ERA Abrogates Angll-Mediated Down-Regulation of IFN- $\gamma$}

Expression of IFN- $\gamma$, a Th1 cytokine, was markedly reduced in groups treated with Angll (Figure 7A; $P<0.005)$. However, this down-regulation returned to baseline in the Angll/ERA group (Figure 7B; $P<0.0001$ ).

\section{Discussion}

In this study, we did not report a significant difference in blood pressure measurements between the Angll and Angll/ERA treatment groups. Although others have shown that ERAs may reduce Angll-mediated hyperten- 

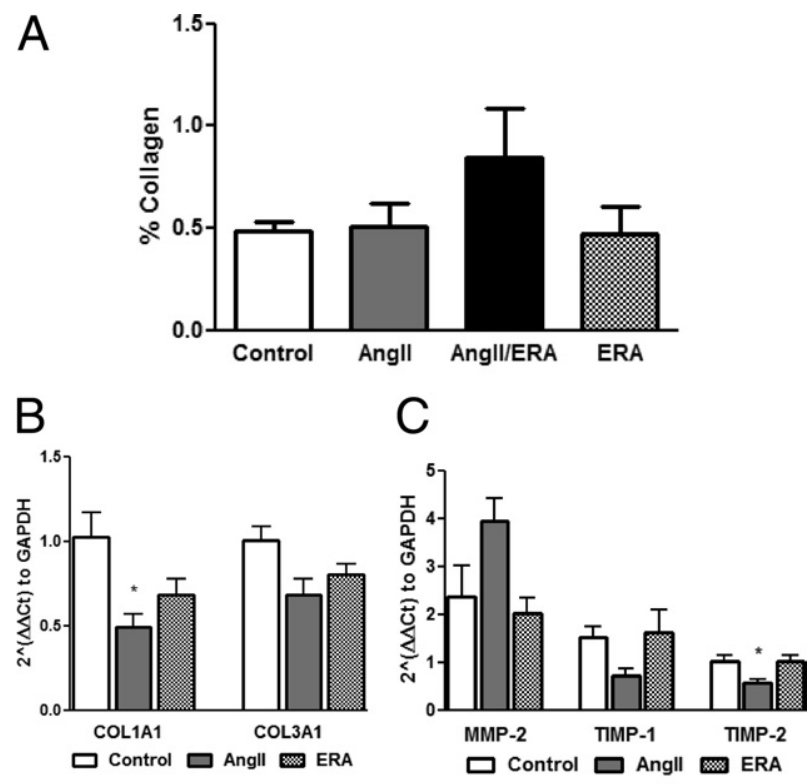

$\mathrm{D}$

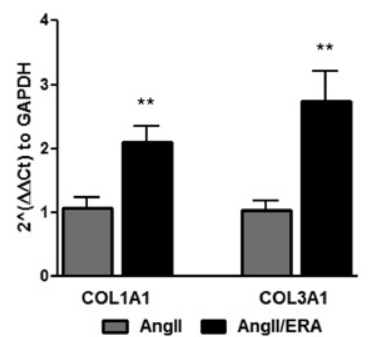

$\mathrm{E}$

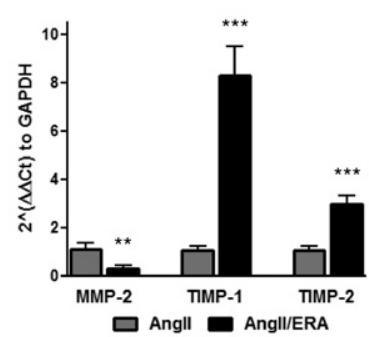

$\mathrm{F}$

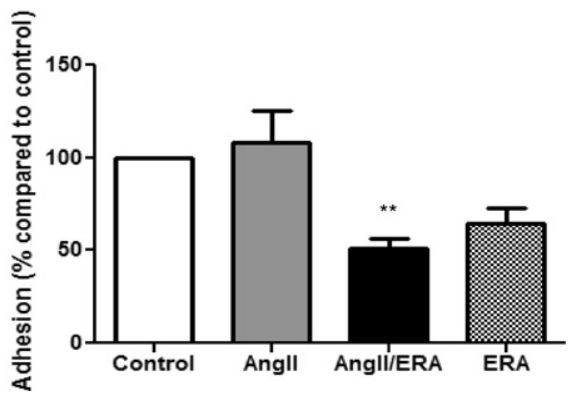

Figure 6. AngII-induced matrix changes in collagen sheets from ascorbatefed A10 cells. A: Total percentage of collagen normalized to total protein. Quantification of mRNA expression (normalized to GAPDH) with the use of quantitative real-time RT-PCR was determined for COL1A1 and COL3A1 (B and D) and for MMP-2, TIMP-1, and TIMP-2 (C and E) after 2 weeks of treatment. $\mathbf{D}$ and E: Unlike treatment with AngII alone, cotreatment with ERA promoted the transcription of profibrosis genes in the AngII-stimulated matrix. F: Adhesion to collagen is significantly reduced by combined treatment of AngII and ERA. Data are presented as means \pm SEMs; for total percentage of collagen, $n=5$ to 6 per group; for RNA studies, $n=4$ per group; for adhesion assay, $n=3$ to 4 per group. ${ }^{*} P<0.05$ versus control; ${ }^{* * *} P<0.05$, ${ }_{* * * * *} P<0.005$ versus AngII.

sion, ${ }^{38}$ differences in specificity [dual ERAs versus ET(A)receptor antagonists], ${ }^{39,40}$ as well as ERA dosage, probably have varying effects on blood pressure. Notably, the ERA dose used in our work is based on a clinically relevant dose of $10 \mathrm{mg} \cdot \mathrm{kg}^{-1} \cdot \mathrm{day}^{-1}$. Our studies showed that ERA significantly reduced the Angll-enhanced lesion progression in young mice and lesion complexity in older mice, suggesting that ET-1 is substantially involved in
Angll-induced atherosclerotic progression. Others have reported a $31 \%$ reduction in lesion area of fat-fed young apoE ${ }^{-1-}$ mice given the ET(A)-receptor antagonist LU135252 for 30 weeks $^{24}$; however, this is the first report that shows inhibition of Angll-induced rapid progression of atherosclerosis with short-term (4-week) ERA treatment. It is well known that Angll can activate NF- $\kappa \mathrm{B}^{20}$ and thereby up-regulate a number of pro-inflammatory genes, including monocyte chemoattractant protein-1 $1^{12,17,20,41}$ and vascular cell adhesion molecule-112,20; data also suggest that ET-1 overexpression can also induce vascular inflammation through similar mechanisms. ${ }^{42,43}$ Our data suggest that the pro-inflammatory effects of Angll in this model can be markedly reduced by ERA, suggesting that ET-1 acts downstream of Angll.

Although a strong association exists between atherosclerosis and AAA, many studies have shown that the extent of atherosclerosis is not correlated to aneurysm development. ${ }^{16,18,41,44}$ Thus, the causal role for atherosclerosis in the pathogenesis of AAA remains in question. In our study, ERA treatment markedly reduced atherosclerotic burden in the aorta but did not reduce AAA incidence in either old or very young animals; interestingly, ERA treatment increased biological markers of AAA progression in the Angll model. It is possible that blocking ET receptor binding only partially inhibits Angll-induced vascular inflammatory responses and in so doing promotes the development of a profibrotic phenotype. Recent studies suggest that conversion from Th1 to Th2 immune responses, including a deficiency in IFN- $\gamma$, are hallmarks of aneurysmal progression. ${ }^{2-4,15}$ Pro-inflammatory Th1 immune responses are predominant in early atherogenesis, ${ }^{2,4,45}$ a potentiation ${ }^{46}$ that was seen in our very young animals. Angll has been shown to induce INF- $\gamma$, a primary mediator of Th1 responses, in lymphocytes, ${ }^{47,48}$ whereas endothelial-derived ET- 1 has been linked to, and possibly modulated by, ${ }^{49}$ INF- $\gamma$ production in a number of disease models. ${ }^{50-52}$ The marked plaque reduction with ERA seen in young mice suggests that, in the forming atheroma, ET-1 signaling is involved in Angllmediated Th1 inflammation. However, Angll was shown to repress INF- $\gamma$ expression in our cultured SMC sheet model which was restored by ERA, suggesting that Angll and ET-1 may have distinctly different effects in the vessel wall compared with T cells; this may in part account
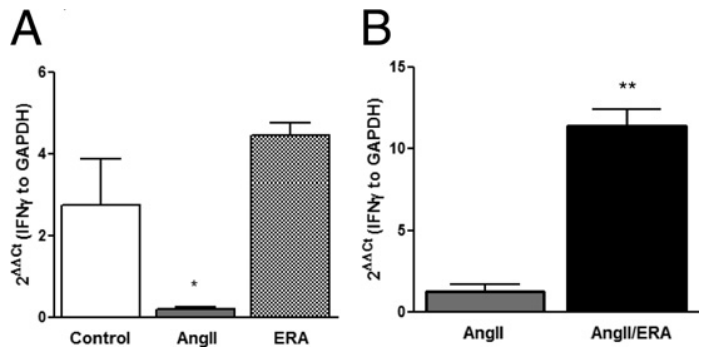

Figure 7. Transcription of interferon INF- $\gamma$ in the A10 SMC collagen sheet model is regulated by AngII and ERA. Quantitative real-time RT-PCR data were quantified after 2 weeks of treatment with AngII and ERA. Downregulation of INF- $\gamma$ mRNA with the single treatment of AngII (A) was enhanced when combined with ERA $(\mathbf{B})$. Data are presented as means \pm SEMs; $n=4$ per group. ${ }^{*} P<0.005$ versus control; ${ }^{* *} P<0.0001$ versus AngII 
for the differential role of ET-1 in aneurysm and atherosclerosis. Although a marked inflammatory response was observed in all aneurysmal aortas, it was predominated by macrophages; in this situation ET-1 may be exerting its primary effect on fibrosis by modulating smooth muscle and macrophage responses.

Mechanical testing of proximal thoracic aortic segments from AAA aortas showed reduced distensibility and increased viscous properties compared with thoracic aortas from non-aneurysmal aortas and vehicletreated controls; this response was most pronounced in Angll/ERA-treated animals with aneurysms. The mechanical findings are consistent with collagen accumulation and an elevated collagen-to-elastin ratio. Our results are consistent with the findings of Tham and colleagues ${ }^{19}$ who showed a marked increase in aortic stiffness with Angll infusion. However, in contrast to previous reports that acute ET-1 exposure stimulates vascular SMC type I collagen formation in vitro, ${ }^{53-55}$ ex vivo ${ }^{56}$ and in vivo, ${ }^{57}$ our data show that in chronic models ERA can enhance collagen deposition in Angll-induced aneurysmal aortas and in A10 collagen sheets. Although Angll has been reported to stimulate type $1^{54,58}$ (probably through ET- ${ }^{53}$ ) and type III collagen synthesis, ${ }^{54,59}$ we found the transcription of both collagen types was only enhanced, in long-term culture studies, with the addition of an ETreceptor blocker. Thus, the effects of ERA on the vasculature are probably context dependent, promoting collagen production only in the presence of a chronic remodeling stimulus such as Angll.

The present experiments also confirmed the ability of Angll to induce MMP-2 expression and to reduce the secretion of its antagonist TIMP-2 in cultured SMC collagen sheets, a result previously reported in endothelial cells. ${ }^{60}$ However, the combination of Angll and ERA decreased MMP-2 expression and increased expression of TIMP-1 and TIMP-2, factors that are conducive to fibrosis because TIMP-2 is known to inhibit active MMP-2 digestion of the formed matrix. Reports in the diabetic rat models found that inhibition of ET(B) markedly increased collagen deposition in mesenteric arteries, whereas ET(A) inhibition reduced collagen content and MMP-2 activity. ${ }^{61}$ Similarly, treatment with sitaxsentan, a ET(A)selective receptor antagonist, suppressed MMP-2 activity and maintained TIMP-1 protein levels in a rat model of late post-myocardial infarction. ${ }^{62}$ These studies reinforce the view that the role of ET-1 in vascular fibrosis is context dependent. In our experiments with ERA we found increased collagen deposition in Angll-treated groups only in the presence of established aneurysms or when SMCs were cultured in collagen sheets. Thus, the response to ERA that we observed may be contextually dependent on the presence or state of the collagen matrix.

Finally, our studies showed that combined treatment of Angll and ERA significantly reduced adhesion to type I collagen and that this may in part be due to decreased $\beta_{1}$-integrin expression in the cells. $\alpha_{1} \beta_{1}$ - and $\alpha_{2} \beta_{1}$-integrins are the main type I collagen receptors, and previous studies have shown that $\alpha_{1} \beta_{1}$-integrins, which are highly expressed in vascular SMCs, ${ }^{63}$ act as negative feedback regulators of collagen synthesis.. ${ }^{64,65}$ Furthermore, a

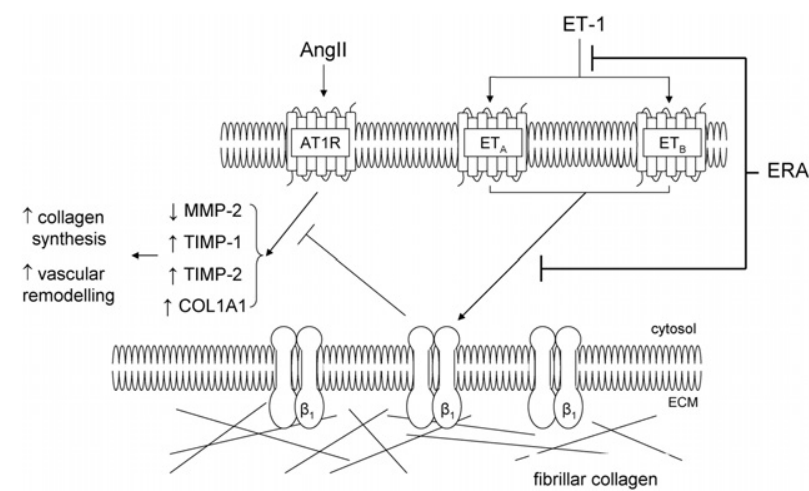

Figure 8. Proposed mechanism for collagen regulation by a dual endothelin $\left(\mathrm{ET}_{\mathrm{A}}\right.$ and $\mathrm{ET}_{\mathrm{B}}$ ) receptor antagonist (ERA) in an AngII-stimulated matrix. AngII initially promotes collagen synthesis by increasing collagen mRNA expression, inhibiting MMPs, and up-regulating TIMPs, while also stimulating ET-1 production, which, over time, negatively regulates collagen synthesis by enhancing $\beta_{1}$-integrin binding to fibrillar collagen. Treatment with an ERA reduces $\beta_{1}$-integrin levels at the membrane, decreases adhesion to the collagen matrix, and releases the negative feedback regulation on collagen. Collagen production is increased beyond that which is seen with AngII treatment alone and propagates vascular remodeling, leading to greater susceptibility to AAAs. In addition, an ERA-induced reduction in integrin expression may also play a role in reducing atherosclerotic plaque burden as has been shown by others. ${ }^{67}$

study by Gardner et al ${ }^{66}$ showed that loss of $\alpha_{1} \beta_{1}$-integrin in fibroblasts resulted in inhibition of this feedback regulation, leading to an increase in dermal collagen deposition in vivo. Similarly, Schapira et $\mathrm{al}^{67}$ demonstrated loss or inhibition of $\alpha_{1} \beta_{1}$-integrin induced enhanced collagen deposition in atherosclerotic mouse arteries. Our experiments suggest that Angll/ERA treatment might also abrogate this negative feedback regulation through decreased cellular adhesion to collagen and decreased $\beta_{1}$-integrin expression, resulting in the up-regulation of collagen mRNA and overall increase in collagen synthesis and fibrotic response (summarized in Figure 8). This mechanism is consistent with our in vivo work and may help to explain the dramatic increase in collagen synthesis we observed in the aneurysmal aortas of apoE-null mice treated with Angll/ERA compared with those treated with Angll alone.

ERA treatment of cardiovascular disease has been controversial in the clinical setting, and therapeutic results seen in animal models (for a review, see Remuzzi et $\mathrm{al}^{68}$ ) have not translated well into humans trials (for a review of clinical trials, see Kelland and Webb ${ }^{69}$ ). Our study raises a possible concern with the suggested therapeutic use of ERA in patients with atherosclerosis. Although there may be a benefit in reducing the early progression of atherosclerosis, there may also be context-dependent effects on vascular matrix remodeling which could enhance fibrotic responses. Our model represents an early stage of aneurysm formation, an initial reparative process, ${ }^{70}$ that involves marked inflammation, the production of cytokines that may result in widespread vascular fibrosis, focal elastin fragmentation, and weakening of the abdominal aortic wall that increases susceptibility to aneurysmal development. In this context it is possible that ET-1 plays a protective role by modulating the deleterious effects of chronic Angll infusion which may underlie the development of AAA. However, in the 
human setting, aneurysms develop over a much longer time course, and the precise role of ET-1 in all stages of this remodeling process is yet to be established.

\section{Acknowledgments}

We thank Dr. Catherine M. Bellingham, Dr. Yupu Deng, Dr. Fred W. Keeley, Dr. Effat Rezaei, Dr. Eva E. Sitarz, Dr. Qiuwang Zhang, and Dr. Yidan Zhao for their technical assistance.

\section{References}

1. Reed D, Reed C, Stemmermann G, Hayashi T: Are aortic aneurysms caused by atherosclerosis? Circulation 1992, 85:205-211

2. Shimizu K, Shichiri M, Libby P, Lee RT, Mitchell RN: Th2-predominant inflammation and blockade of IFN-gamma signaling induce aneurysms in allografted aortas. J Clin Invest 2004, 114:300-308

3. Shimizu K, Mitchell RN, Libby P: Inflammation and cellular immune responses in abdominal aortic aneurysms. Arterioscler Thromb Vasc Biol 2006, 26:987-994

4. Schonbeck U, Sukhova GK, Gerdes N, Libby P: T(H)2 predominant immune responses prevail in human abdominal aortic aneurysm. Am J Pathol 2002, 161:499-506

5. Curci JA, Liao S, Huffman MD, Shapiro SD, Thompson RW: Expression and localization of macrophage elastase (matrix metalloproteinase-12) in abdominal aortic aneurysms. J Clin Invest 1998, 102: $1900-1910$

6. Pyo R, Lee JK, Shipley JM, Curci JA, Mao D, Ziporin SJ, Ennis TL, Shapiro SD, Senior RM, Thompson RW: Targeted gene disruption of matrix metalloproteinase-9 (gelatinase B) suppresses development of experimental abdominal aortic aneurysms [see comments]. J Clin Invest 2000, 105:1641-1649

7. McCormick ML, Gavrila D, Weintraub NL: Role of oxidative stress in the pathogenesis of abdominal aortic aneurysms. Arterioscler Thromb Vasc Biol 2007, 27:461-469

8. Dimmeler S, Rippmann V, Weiland U, Haendeler J, Zeiher AM: Angiotensin II induces apoptosis of human endothelial cells. Protective effect of nitric oxide. Circ Res 1997, 81:970-976

9. Keidar S: Angiotensin. LDL peroxidation and atherosclerosis. Life Sci 1998, 63:1-11

10. Cassis LA, Gupte M, Thayer S, Zhang X, Charnigo R, Howatt DA, Rateri DL, Daugherty A: ANG II infusion promotes abdominal aortic aneurysms independent of increased blood pressure in hypercholesterolemic mice. Am J Physiol Heart Circ Physiol 2009, 296:H1660H1665

11. Daugherty A, Cassis L: Chronic angiotensin II infusion promotes atherogenesis in low density lipoprotein receptor-/- mice. Ann N Y Acad Sci 1999, 892:108-118

12. da Cunha V. Tham DM, Martin-McNulty B, Deng G, Ho JJ, Wilson DW Rutledge JC, Vergona R, Sullivan ME, Wang YX: Enalapril attenuates angiotensin II-induced atherosclerosis and vascular inflammation. Atherosclerosis 2005, 178:9-17

13. Daugherty A, Manning MW, Cassis LA: Angiotensin II promotes atherosclerotic lesions and aneurysms in apolipoprotein E-deficient mice. J Clin Invest 2000, 105:1605-1612

14. Gavrila D, Li WG, McCormick ML, Thomas M, Daugherty A, Cassis LA, Miller FJ, Jr., Oberley LW, Dellsperger KC, Weintraub NL: Vitamin $\mathrm{E}$ inhibits abdominal aortic aneurysm formation in angiotensin IIinfused apolipoprotein E-deficient mice. Arterioscler Thromb Vasc Biol 2005, 25:1671-1677

15. King VL, Lin AY, Kristo F, Anderson TJ, Ahluwalia N, Hardy GJ, Owens AP, III, Howatt DA, Shen D, Tager AM, Luster AD, Daugherty $A$, Gerszten RE: Interferon-gamma and the interferon-inducible chemokine CXCL10 protect against aneurysm formation and rupture. Circulation 2009, 119:426-435

16. Manning MW, Cassis LA, Daugherty A: Differential effects of doxycycline, a broad-spectrum matrix metalloproteinase inhibitor, on angiotensin II-induced atherosclerosis and abdominal aortic aneurysms. Arterioscler Thromb Vasc Biol 2003, 23:483-488
17. Ni W, Kitamoto S, Ishibashi M, Usui M, Inoue S, Hiasa K, Zhao Q, Nishida K, Takeshita A, Egashira K: Monocyte chemoattractant protein-1 is an essential inflammatory mediator in angiotensin II-induced progression of established atherosclerosis in hypercholesterolemic mice. Arterioscler Thromb Vasc Biol 2004, 24:534-539

18. Saraff K, Babamusta F, Cassis LA, Daugherty A: Aortic dissection precedes formation of aneurysms and atherosclerosis in angiotensin II-infused apolipoprotein E-deficient mice. Arterioscler Thromb Vasc Biol 2003, 23:1621-1626

19. Tham DM, Martin-McNulty B, Wang YX, da C, V, Wilson DW, Athanassious CN, Powers AF, Sullivan ME, Rutledge JC: Angiotensin II injures the arterial wall causing increased aortic stiffening in apolipoprotein E-deficient mice. Am J Physiol Regul Integr Comp Physiol 2002, 283:R1442-R1449

20. Tham DM, Martin-McNulty B, Wang YX, Wilson DW, Vergona R, Sullivan ME, Dole W, Rutledge JC: Angiotensin II is associated with activation of NF-kappaB-mediated genes and downregulation of PPARs. Physiol Genomics 2002, 11:21-30

21. Weiss D, Kools JJ, Taylor WR: Angiotensin Il-induced hypertension accelerates the development of atherosclerosis in Apo E-deficient mice. Circulation 2001, 103:448-454

22. Daugherty A, Rateri DL, Cassis LA: Role of the renin-angiotensin system in the development of abdominal aortic aneurysms in animals and humans. Ann N Y Acad Sci 2006, 1085:82-91

23. Daugherty A. Cassis LA: Mouse models of abdominal aortic aneurysms. Arterioscler Thromb Vasc Biol 2004, 24:429-434

24. Barton M, Haudenschild CC, d'Uscio LV, Shaw S, Munter K, Luscher TF: Endothelin ETA receptor blockade restores NO-mediated endothelial function and inhibits atherosclerosis in apolipoprotein E-deficient mice. Proc Natl Acad Sci U S A 1998, 95:14367-14372

25. Babaei S, Picard P, Ravandi A, Monge JC, Lee TC, Cernacek $P$, Stewart DJ: Blockade of endothelin receptors markedly reduces atherosclerosis in LDL receptor deficient mice: role of endothelin in macrophage foam cell formation. Cardiovasc Res 2000, 48:158-167

26. Bousette N, Giaid A: Endothelin-1 in atherosclerosis and other vasculopathies. Can J Physiol Pharmacol 2003, 81:578-587

27. Sung CP, Arleth AJ, Storer BL, Ohlstein EH: Angiotensin type 1 receptors mediate smooth muscle proliferation and endothelin biosynthesis in rat vascular smooth muscle. J Pharmacol Exp Ther 1994, 271:429-437

28. Moreau P, d'Uscio LV, Shaw S, Takase H, Barton M, Luscher TF: Angiotensin II increases tissue endothelin and induces vascular hypertrophy: reversal by ET(A)-receptor antagonist. Circulation 1997 , 96:1593-1597

29. Huszar G, Maiocco J, Naftolin F: Monitoring of collagen and collagen fragments in chromatography of protein mixtures. Anal Biochem 1980, 105:424-429

30. Zhang L, Tran N, Chen HQ, Kahn CJ, Marchal S, Groubatch F, Wang $X$ : Time-related changes in expression of collagen types I and III and of tenascin- $\mathrm{C}$ in rat bone mesenchymal stem cells under co-culture with ligament fibroblasts or uniaxial stretching. Cell Tissue Res 2008 , 332:101-109

31. He JZ, Quan A, Xu Y, Teoh H, Wang G, Fish JE, Steer BM, Itohara S, Marsden PA, Davidge ST, Ward ME: Induction of matrix metalloproteinase-2 enhances systemic arterial contraction after hypoxia. Am J Physiol Heart Circ Physiol 2007, 292:H684-H693

32. Reddick RL, Zhang SH, Maeda N: Atherosclerosis in mice lacking apo E. Evaluation of lesional development and progression [published erratum appears in Arterioscler Thromb 1994, 14(5):839]. Arterioscler Thromb 1994, 14:141-147

33. Zhang SH, Reddick RL, Piedrahita JA, Maeda N: Spontaneous hypercholesterolemia and arterial lesions in mice lacking apolipoprotein E. Science 1992, 258:468-471

34. Qiao H, Bell J, Juliao S, Li L, May JM: Ascorbic acid uptake and regulation of type I collagen synthesis in cultured vascular smooth muscle cells. J Vasc Res 2008, 46:15-24

35. Davidson JM, LuValle PA, Zoia O, Quaglino D Jr, Giro M: Ascorbate differentially regulates elastin and collagen biosynthesis in vascular smooth muscle cells and skin fibroblasts by pretranslational mechanisms. J Biol Chem 1997, 272:345-352

36. Bishop JE, Laurent GJ: Collagen turnover and its regulation in the normal and hypertrophying heart. Eur Heart J 1995, 16(Suppl C): $38-44$ 
37. Fouser L, Sage EH, Clark J, Bornstein P: Feedback regulation of collagen gene expression: a Trojan horse approach. Proc Natl Acad Sci U S A 1991, 88:10158-10162

38. Rajagopalan S, Laursen JB, Borthayre A, Kurz S, Keiser J, Haleen S, Giaid A, Harrison DG: Role for endothelin-1 in angiotensin II-mediated hypertension. Hypertension 1997, 30:29-34

39. Schneider MP, Boesen El, Pollock DM: Contrasting actions of endothelin $\mathrm{ET}(\mathrm{A})$ and $\mathrm{ET}(\mathrm{B})$ receptors in cardiovascular disease. Annu Rev Pharmacol Toxicol 2007, 47:731-759

40. Dupuis J, Hoeper MM: Endothelin receptor antagonists in pulmonary arterial hypertension. Eur Respir J 2008, 31:407-415

41. Ayabe N, Babaev VR, Tang Y, Tanizawa T, Fogo AB, Linton MF, Ichikawa I, Fazio S, Kon V: Transiently heightened angiotensin II has distinct effects on atherosclerosis and aneurysm formation in hyperlipidemic mice. Atherosclerosis 2006, 184:312-321

42. Amiri F, Paradis P, Reudelhuber TL, Schiffrin EL: Vascular inflammation in absence of blood pressure elevation in transgenic murine model overexpressing endothelin-1 in endothelial cells. J Hypertens 2008, 26:1102-1109

43. Woods M, Wood EG, Bardswell SC, Bishop-Bailey D, Barker S, Wort SJ, Mitchell JA, Warner TD: Role for nuclear factor-kappaB and signal transducer and activator of transcription 1/interferon regulatory factor-1 in cytokine-induced endothelin-1 release in human vascular smooth muscle cells. Mol Pharmacol 2003, 64:923-931

44. Johnsen SH, Forsdahl SH, Singh K, Jacobsen BK: Atherosclerosis in abdominal aortic aneurysms: a causal event or a process running in parallel? The Tromso study. Arterioscler Thromb Vasc Biol 2010, 30:1263-1268

45. Frostegard J, Ulfgren AK, Nyberg P, Hedin U, Swedenborg J, Andersson U, Hansson GK: Cytokine expression in advanced human atherosclerotic plaques: dominance of pro-inflammatory (Th1) and macrophage-stimulating cytokines. Atherosclerosis 1999, 145:33-43

46. Gupta S, Pablo AM, Jiang X, Wang N, Tall AR, Schindler C: IFNgamma potentiates atherosclerosis in ApoE knock-out mice. J Clin Invest 1997, 99:2752-2761

47. Mazzolai L, Duchosal MA, Korber M, Bouzourene K, Aubert JF, Hao H, Vallet V, Brunner HR, Nussberger J, Gabbiani G, Hayoz D: Endogenous angiotensin II induces atherosclerotic plaque vulnerability and elicits a Th1 response in ApoE-/- mice. Hypertension 2004, 44:277282

48. Sagawa K, Nagatani K, Komagata Y, Yamamoto K: Angiotensin receptor blockers suppress antigen-specific T cell responses and ameliorate collagen-induced arthritis in mice. Arthritis Rheum 2005, 52 : 1920-1928

49. Lamas S, Michel T, Collins T, Brenner BM, Marsden PA: Effects of interferon-gamma on nitric oxide synthase activity and endothelin-1 production by vascular endothelial cells. J Clin Invest 1992, 90:879_ 887

50. Finsnes F, Lyberg T, Christensen G, Skjonsberg OH: Effect of endothelin antagonism on the production of cytokines in eosinophilic airway inflammation. Am J Physiol Lung Cell Mol Physiol 2001, 280: L659-L665

51. Sampaio AL, Rae GA, Henriques MM: Role of endothelins on lymphocyte accumulation in allergic pleurisy. J Leukoc Biol 2000, 67: 189-195

52. Yang LL, Gros R, Kabir MG, Sadi A, Gotlieb Al, Husain M, Stewart DJ: Conditional cardiac overexpression of endothelin-1 induces inflammation and dilated cardiomyopathy in mice. Circulation 2004, 109 255-261

53. Fakhouri F, Placier S, Ardaillou R, Dussaule JC, Chatziantoniou C: Angiotensin II activates collagen type I gene in the renal cortex and aorta of transgenic mice through interaction with endothelin and TGF-beta. J Am Soc Nephrol 2001, 12:2701-2710
54. Rizvi MA, Katwa L, Spadone DP, Myers PR: The effects of endothelin-1 on collagen type I and type III synthesis in cultured porcine coronary artery vascular smooth muscle cells. J Mol Cell Cardiol 1996, 28:243-252

55. Rodriguez-Vita J, Ruiz-Ortega M, Ruperez M, Esteban V, SanchezLopez E, Plaza JJ, Egido J: Endothelin-1, via ETA receptor and independently of transforming growth factor-beta, increases the connective tissue growth factor in vascular smooth muscle cells. Circ Res 2005, 97:125-134

56. Flamant M, Tharaux PL, Placier S, Henrion D, Coffman T, Chatziantoniou C, Dussaule JC: Epidermal growth factor receptor trans-activation mediates the tonic and fibrogenic effects of endothelin in the aortic wall of transgenic mice. FASEB J 2003, 17:327-329

57. Morton LF, Barnes MJ: Collagen polymorphism in the normal and diseased blood vessel wall. Investigation of collagens types I, III and V. Atherosclerosis 1982, 42:41-51

58. Ford CM, Li S, Pickering JG: Angiotensin II stimulates collagen synthesis in human vascular smooth muscle cells. Involvement of the AT(1) receptor, transforming growth factor-beta, and tyrosine phosphorylation. Arterioscler Thromb Vasc Biol 1999, 19:1843-1851

59. Wang YX, da Cunha V, Martin-McNulty B, Vincelette J, Li W, Choy DF, Halks-Miller M, Mahmoudi M, Schroeder M, Johns A, Light DR, Dole WP: Inhibition of Rho-kinase by fasudil attenuated angiotensin IIinduced cardiac hypertrophy in apolipoprotein E deficient mice. Eur J Pharmacol 2005, 512:215-222

60. Arenas IA, Xu Y, Lopez-Jaramillo P, Davidge ST: Angiotensin IIinduced MMP-2 release from endothelial cells is mediated by TNFalpha. Am J Physiol Cell Physiol 2004, 286:C779-C784

61. Sachidanandam K, Portik-Dobos V, Harris AK, Hutchinson JR, Muller $\mathrm{E}$, Johnson $\mathrm{MH}$, Ergul $\mathrm{A}$ : Evidence for vasculoprotective effects of ETB receptors in resistance artery remodeling in diabetes. Diabetes 2007, 56:2753-2758

62. Podesser BK, Siwik DA, Eberli FR, Sam F, Ngoy S, Lambert J, Ngo K, Apstein CS, Colucci WS: ET(A)-receptor blockade prevents matrix metalloproteinase activation late postmyocardial infarction in the rat. Am J Physiol Heart Circ Physiol 2001, 280:H984-H991

63. Belkin VM, Belkin AM, Koteliansky VE: Human smooth muscle VLA-1 integrin: purification, substrate specificity, localization in aorta, and expression during development. J Cell Biol 1990, 111:2159-2170

64. Langholz O, Rockel D, Mauch C, Kozlowska E, Bank I, Krieg T, Eckes $\mathrm{B}$ : Collagen and collagenase gene expression in three-dimensional collagen lattices are differentially regulated by alpha 1 beta 1 and alpha 2 beta 1 integrins. J Cell Biol 1995, 131:1903-1915

65. Broberg A, Nissinen L, Potila M, Heino J: Three-dimensional collagen regulates collagen gene expression by a mechanism that requires serine/threonine kinases and is independent of mechanical contraction. Biochem Biophys Res Commun 2001, 280:328-333

66. Gardner H, Broberg A, Pozzi A, Laato M, Heino J: Absence of integrin alpha1beta1 in the mouse causes loss of feedback regulation of collagen synthesis in normal and wounded dermis. J Cell Sci 1999 112(Pt 3):263-272

67. Schapira K, Lutgens E, de Fougerolles A, Sprague A, Roemen A, Gardner H, Koteliansky V, Daemen M, Heeneman S: Genetic deletion or antibody blockade of alpha1beta1 integrin induces a stable plaque phenotype in ApoE-/- mice. Arterioscler Thromb Vasc Biol 2005, 25:1917-1924

68. Remuzzi G, Perico N, Benigni A: New therapeutics that antagonize endothelin: promises and frustrations. Nat Rev Drug Discov 2002, 1:986-1001

69. Kelland NF, Webb DJ: Clinical trials of endothelin antagonists in heart failure: a question of dose? Exp Biol Med 2006, 231:696-699

70. Satta J, Haukipuro K, Kairaluoma MI, Juvonen T: Aminoterminal propeptide of type III procollagen in the follow-up of patients with abdominal aortic aneurysms. J Vasc Surg 1997, 25:909-915 